\title{
SHEARING STRENGTH TEST OF ORTHOPAEDIC TITANIUM ALLOY SCREW PRODUCED IN THE PROCESS OF 3D PRINTING TECHNOLOGY
}

\author{
Patrycja Ruszniak', Jerzy Józwik², Dawid Ostrowski ${ }^{3}$, Krzysztof Dziedzic $^{4}$ \\ 1 Lublin University of Technology, Mechanical Engineering Faculty, Student Scientific Group, Department of \\ Production Engineering, Nadbystrzycka Street 36, 20-816 Lublin, Poland \\ 2 Lublin University of Technology, Mechanical Engineering Faculty, Department of Production Engineering, \\ Nadbystrzycka Street 36, 20-816 Lublin, Poland, e-mail: j.jozwik@pollub.pl \\ 3 The State School of Higher Education, The Institute of Technical Sciences and Aviation, 54 Pocztowa Street, \\ 22-100 Chełm, Poland \\ ${ }^{4}$ Department of Fundamental of Technology, Fundamentals of Technology Faculty, Lublin University of \\ Technology, ul. Nadbystrzycka 38, 20-618 Lublin, Poland, e-mail: k.dziedzic@pollub.pl
}

Received: 2016.12.15

Accepted: 2017.02.01

Published: 2017.03.01

\begin{abstract}
The aim of the present article is the assessment of technical shear resistance (technological shear) of orthopedic screw made of titanium alloy Ti6Al4V, produced using incremental technology in the process of 3D printing process. The first part of the work presents incremental techniques in production engineering. The second part of the present work contains a specification of the $3 \mathrm{D}$ printing process of samples as well as the description of the used material. The fundamental part of the article is composed out of endurance tests for orthopaedic screws as well as the analysis of the obtained results and conclusions. The method of incremental production SLM using SLM $280^{\mathrm{HL}}$ metal printer was used during the technological process. The resistance tests were performed using ZWICK/ROELL Z150 machines. Identical endurance trials were performed for monolithic bars made of titanium alloys (of bar core size ) made on a wire electric discharge machine Sodick SL600Q for comparative purposes. The obtained test results enabled comparative assessment of the value of shear resistance $\mathrm{R}_{\mathrm{t}}$ in the conditions of technological shear. According to the performed tests, the shear resistance $\mathrm{R}_{\mathrm{t}}$ of orthopaedic screws is nearly $33 \%$ lower than of monolithic bars of the same core size.
\end{abstract}

Keywords: 3D printing, incremental technologies, a titanium alloy, the shear stress, orthopaedic screws.

\section{INTRODUCTION}

Strong competition in the market causes continuous improvement and the emergence of new technologies and products. An example of such changes is the rapid development of additive manufacturing technologies. The literature $[1 \div 2,7 \div 9]$ indicates that additive manufacturing technologies, by means of which it is possible to perform various types of components, have a long and successful history of use in the industry. This applies mainly to the components which occur in- dividually, or the ones which must be adapted to the rest of the structure or are so complex that it is impossible to obtain them by means of other technologies. There are many methods that allow one to obtain parts through the process of 3D printing. Manufacturers generate more and more modern techniques whose goal is to improve product quality and reduce production costs. Due to continuous improvements and a wide range of applications, additive manufacturing technology is becoming increasingly popular $[3 \div 6,10,11 \div 14]$. According to the literature, components made of 
biomaterials with a high proportion of titanium alloys gain a growing importance in medicine. This occurs due to, among others, biocompatibility that characterizes this material. Titanium alloys are used for the manufacture of, inter alia, implants and prostheses $[1,4,12]$. An important problem is still the issue of obtaining a lasting connection between the implant and bone tissue, which after prolonged use would not lead to loosening of the implant. The main advantages of titanium and titanium alloys are high corrosion resistance, low density, and other properties, which include: biocompatibility that indicates proper functioning in a living organism, very low modulus of elasticity, which has a major influence on the formation of bone implants and high fatigue strength [2,4]. The Ti6Al4V alloy (Grade 5) has broad industrial and medical applications. It is a two-phase alloy of $\alpha+\beta$ structure [13].

\section{ADDITIVE MANUFACTURING TECHNO- LOGIES IN PRODUCTION ENGINEERING}

In case of additive manufacturing technologies, the constructed object is performed as a result of applying subsequent layers of the material. This can be done by curing a liquid (resin), plasticizing a polymer and sintering or melting a powder. "Flat" layers of a coated material combine together to form a single, three-dimensional model. The thickness of the material applied during the printing process is the main parameter which determines its accuracy. Currently, most of the machines perform layers with a thickness of $0.1 \mathrm{~mm}$ or less. There is a need for a very large number of layers and time for the construction of a several-centimetre model. Therefore, modern 3D printers are numerically controlled and run at high speeds. The movement-based programming is carried out using a specialized computer software [3]. The 1980s were the beginning of a number of different additive manufacturing methods. Many technologies have been withdrawn, but the remaining technologies are still being developed. Currently, the most popular are [3]: SLA (Stereolitography), LOM (Laminated Object Manufacturing), SLS (Selective Laser Sintering), SLM (Selective Laser Melting), EBM (Electron Beam Melting), FDM (Fused Deposition Modelling), JM (Jet Modelling), 3DP (Three-Dimensional Printing), DLP (Digital Light Processor), LENS (Laser Engineering Net Shaping).
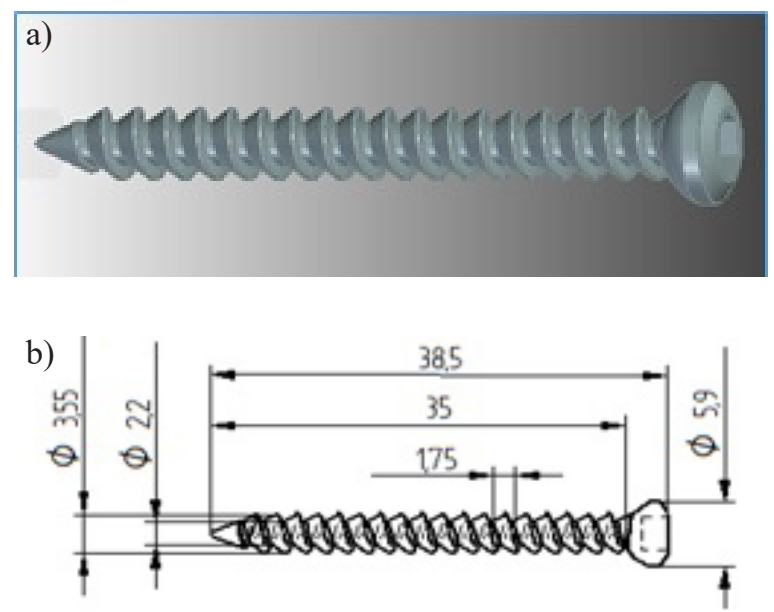

Fig. 1. The view of a screw designed for the research: a) $3 \mathrm{D}$, b) $2 \mathrm{D}$

\section{EMPIRICAL RESEARCH}

\section{Description of the model}

The first stage of the research was to construct a model of a screw, designed to secure the nails and plates connecting the damaged bones. The screw model was designed in the Solid Edge ST6 environment. Figure 1a shows it in 3D format, and Figure $1 \mathrm{~b}$ shows the screw in 2D format.

The geometrical dimensions of an exemplary screw were determined on the basis of catalogues belonging to healthcare companies and are given in Figure 1b.

\section{The material used}

The screws which are the subject of the present research were made of the Ti6Al4V titanium alloy. The Ti6A14V alloy is most commonly used in aviation and medicine. The reason for its different applications are its mechanical and physical properties. Table 1 shows properties of the Ti6Al4V titanium alloy, while Table 2 gives chemical composition of the alloy according to ISO 5832/3 [5]. The selective laser melting method SLM was used to construct the screws. The SLM method produces components with a uniform, almost pore-free structure and its mechanical characteristics are within the specification of a given material. The subsequent processing, for example thermal or thermo-chemical, adjusts these properties to the desired requirements.

The Ti6Al4V alloy, among other things, belongs to a group of biomaterials. It is applied to a variety of implants. These include plates, or- 
Table 1. Parameters of the Ti6Al4V titanium alloy [6]

\begin{tabular}{|l|c|c|}
\hline \multicolumn{1}{|c|}{ Parameters } & Symbol and unit & Ti6Al4V \\
\hline Tensile strength & $\mathrm{R}_{\mathrm{m}}[\mathrm{MPa}]$ & $1286 \pm 57$ \\
\hline Yield strength & $\mathrm{R}_{\mathrm{p} 0,2}[\mathrm{MPa}]$ & $1116 \pm 61$ \\
\hline Relative elongation at break & $\mathrm{A}[\%]$ & $8 \pm 2$ \\
\hline Young's modulus & $\mathrm{E}[\mathrm{GPa}]$ & $111 \pm 4$ \\
\hline Vickers Hardness & {$\left[\mathrm{HV} \mathrm{f}_{10}\right]$} & $384 \pm 5$ \\
\hline Parameter of the surface roughness $\mathrm{R}_{\mathrm{a}}$ & $\mathrm{R}_{\mathrm{a}}[\mu \mathrm{m}]$ & $12 \pm 1$ \\
\hline Parameter of the surface roughness $\mathrm{R}_{\mathrm{z}}$ & $\mathrm{R}_{\mathrm{z}}[\mu \mathrm{m}]$ & $70 \pm 3$ \\
\hline
\end{tabular}

Table 2. Chemical composition of the Ti6Al4V titanium alloy according to ISO 5832/3 [5]

\begin{tabular}{|c|c|c|c|c|c|c|c|}
\hline \multicolumn{7}{|c|}{ The concentration of elements \% } \\
\hline $\mathrm{O}$ & $\mathrm{V}$ & $\mathrm{Al}$ & $\mathrm{Fe}$ & $\mathrm{H}$ & $\mathrm{C}$ & $\mathrm{N}$ & $\mathrm{Ti}$ \\
\hline$<0,20$ & 3,5 & 5,5 & $<0,30$ & $<0,0015$ & $<0,08$ & $<0,05$ & the rest \\
\hline
\end{tabular}

thopaedic screws, nails, prostheses, as well as all kinds of prosthetic products.

\section{Printing}

The next stage of the research was the implementation of the printing process. The printing process was carried out on a 3D printer for metal - SLM 280 HL, enabling the implementation of SLM technologies (Fig. 2). Both the method and the device enable the use of various types of metal alloy powders, such as: titanium, magnesium, cobalt, chromium, copper, aluminium, tungsten, tool steel or stainless steel. It allows to obtain medical implants, machine parts, cutting tools, blanking dies, moulds or matrices. The entire process of $3 \mathrm{D}$ printing was carried out in an inert gas [6].

To enable printing of the designed screws, it was necessary to set the models on a virtual platform under Materialise Magics software,

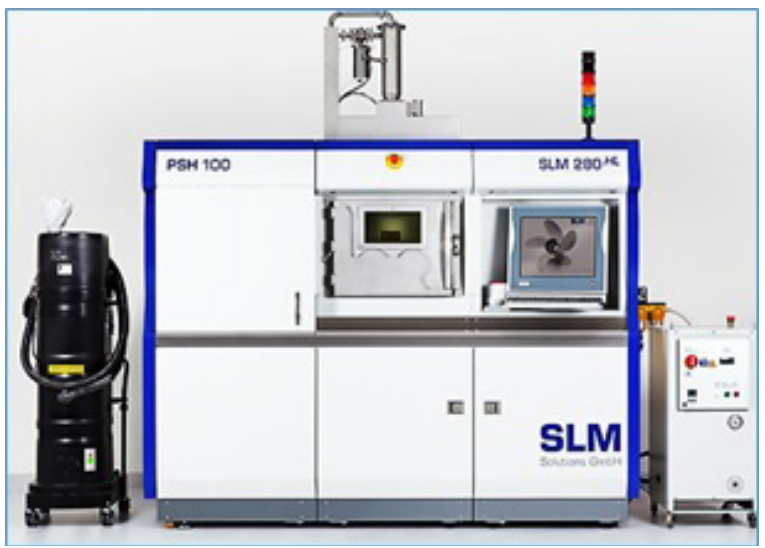

Fig. 2. 3D printer for metal - SLM $280^{\mathrm{HL}}[40]$ which is presented in Figure 3a. Figure 3a also shows an orthopaedic nail that cooperates with orthopaedic screws. Figure $3 \mathrm{~b}$ presents printed screws on the platform, along with the accordingly designed supports.

Materialise Magics is used to prepare an element for printing, but it can also be used to "fix the geometry", orientation of components in
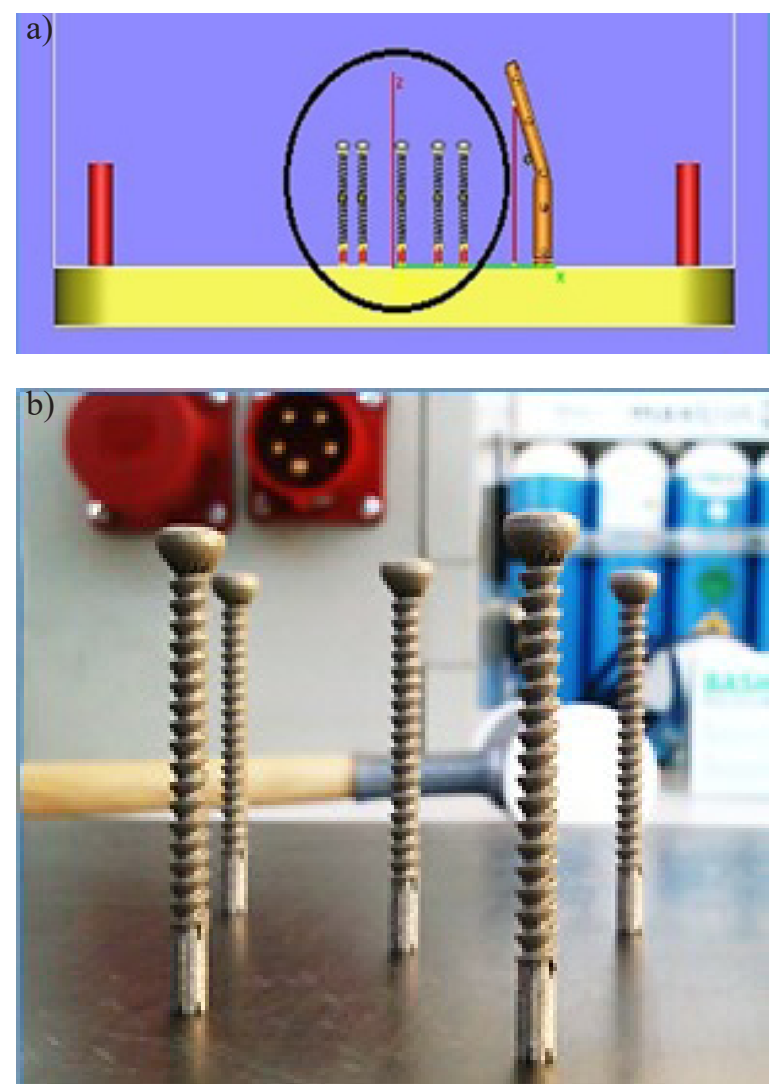

Fig. 3. Location of screws: a) location of screws before the printing process in Materialise Magics, b) printed screws on the platform with designed supports 
Table 3. Geometric and technological parameters of 3D printing process

\begin{tabular}{|c|c|c|c|c|c|c|}
\hline$\frac{2}{4}$ & $\begin{array}{l}\text { Volume of the } \\
\text { screw }\left[\mathrm{mm}^{3}\right]\end{array}$ & $\begin{array}{c}\text { Density of the } \\
\text { material }\left[\mathrm{g} / \mathrm{cm}^{3}\right]\end{array}$ & $\begin{array}{c}\text { Thickness of a single } \\
\text { layer [mm] }\end{array}$ & $\begin{array}{c}\text { Laser } \\
\text { power [W] }\end{array}$ & $\begin{array}{c}\text { Scanning speed } \\
{[\mathrm{mm} / \mathrm{s}]}\end{array}$ & $\begin{array}{c}\text { Distance between } \\
\text { scan lines [mm] }\end{array}$ \\
\hline$\frac{\bar{\pi}}{\frac{\pi}{\pi}}$ & 258 & 4,5 & 0,03 & 100 & 525 & 0,12 \\
\hline
\end{tabular}

space, selection of appropriate supports, etc. The so-called Build Processor was used to establish the type of material, building strategies, selection of process parameters. Each manufacturer adapts it to their own machine, which is integrated with Materialise Magics. It allows to prepare a file with information about the entire process (in *.slm format), which is then "transferred to the machine". Table 3 presents geometrical quantities determined with the use of Build Processor and technological parameters of the printing process. As is apparent from Figure 3b, each of the screws has respective supports in the lower part (due to the lack of a suitable flat surface where it could be built) that allow printing of samples with all geometric details.

\section{STRENGTH TESTS}

\section{Description of a special handle}

The next stage of empirical research was to conduct technological shearing strength tests. A special handle shown in Figure 4, enabling the execution of technological shearing, was designed and manufactured to conduct these tests. The designed and manufactured handle was adjusted to ensure that the sample can be properly mounted onto the strength machine. The handle consists of two parts (the lower beam and brackets) equipped with through holes that allow for the attachment of printed screws. Figure 4 a and $\mathrm{b}$ present a model of the handle and its view after the necessary technological operations (Fig. 4 c).

The handle was made of N9E tool steel and was then subject to hardening. This made it possible to achieve higher hardness of components necessary to carry out the research process. The handle was characterized by high strength, and the backlash-free movement of the bands during tests helped to minimize the impact of bending on the sizes recorded during the tests. In principle, the simultaneously occurring stresses caused by bending (which in most cases occur in the case of riveted or welded joints) are omitted during technological shearing.

\section{Stand for strength tests}

Strength tests were conducted with the use of ZWICK/ROELL Z150 (Fig. 5a). The ZWICK/ ROELL Z150 testing machine allows to conduct research relating to inter alia: compression, tensile, bending, shearing in elevated and reduced temperatures. Because of the thermal and cooling chamber it enables the implementation of a)

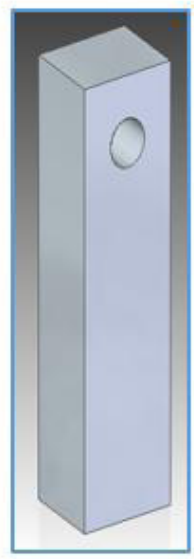

b)

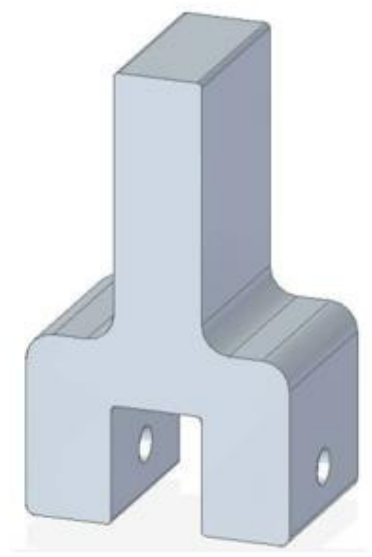

c)

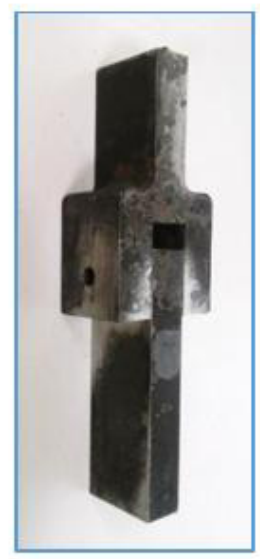

Fig. 4. A special handle used to mount research samples: a) model of the lower beam, b) model of brackets, c) view of the handle after performing and hardening 
Table 4. Assumptions for strength tests

\begin{tabular}{|c|c|c|c|c|c|c|}
\hline \multirow{2}{*}{ Parameters } & $\begin{array}{c}\text { Initial } \\
\text { force }\end{array}$ & $\begin{array}{c}\text { Tensile } \\
\text { speed }\end{array}$ & $\begin{array}{c}\text { The core diameter } \\
\text { of printed screw }\end{array}$ & $\begin{array}{c}\text { The core diameter } \\
\text { of printed screw }\end{array}$ & $\begin{array}{c}\text { The core diameter } \\
\text { of printed screw }\end{array}$ & $\begin{array}{c}\text { The core diameter } \\
\text { of printed screw }\end{array}$ \\
\cline { 2 - 7 } & $20 \mathrm{~N}$ & $5 \mathrm{~mm} / \mathrm{min}$ & $2,2 \mathrm{~mm}$ & $2,2 \mathrm{~mm}$ & $38,5 \mathrm{~mm}$ & $38,5 \mathrm{~mm}$ \\
\hline
\end{tabular}

strength tests in temperature ranging from -40 to $+240^{\circ} \mathrm{C}$. The maximum breaking strength for this model of the machine is $150 \mathrm{kN}$. The screws were placed in the previously constructed special holder, as demonstrated in fig. $5 \mathrm{~b}$. The jaws of the testing machine grab the special handle at the length of $4 \mathrm{~cm}$ what ensures the stability of attachment during research trials. Assumptions for breaking were presented in Table 4.

Shearing tests of titanium alloy cores with a section equal to the core of orthopaedic screws were made for comparative purposes.

The number of rods was determined by the number of screws. They were made on the Sodick SL600Q wire electric discharge machine that was depicted in Figure 6. The initial parameters when breaking the rods were the same as in case of the screws.

\section{Comparative study of immediate strength on shearing of orthopaedic screws - test results}

Strength test related to a series of orthopaedic screws made in 3D printing technology and

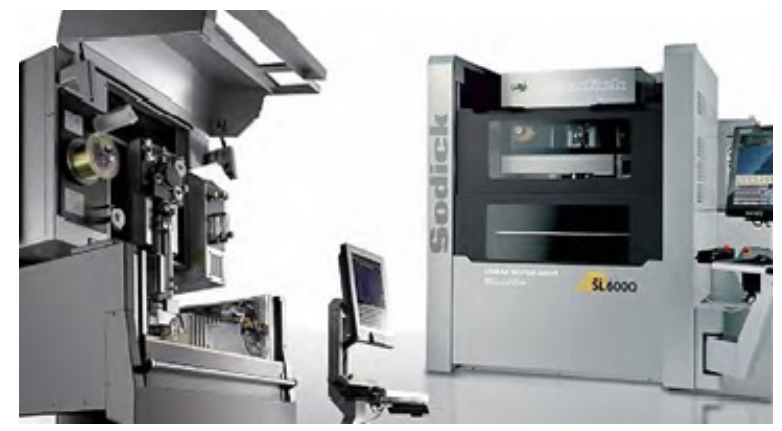

Fig. 6. The Sodick SL600Q wire electric discharge machine

rods with a diameter equal to the diameter of the screw core. Figure $7 \mathrm{a}$ and $\mathrm{b}$ present the subject of research, and Figure 7c and d present corresponding samples after the shearing process. The rods used during the tests were used to conduct a comparative evaluation of shearing strength.

Figure $8 \mathrm{a}$ presents courses of force changes as a function of the elongation registered for certain orthopaedic screws. Based on the graphs from Figure 8a one can observe diverse course of force changes for shearing test with visible a)

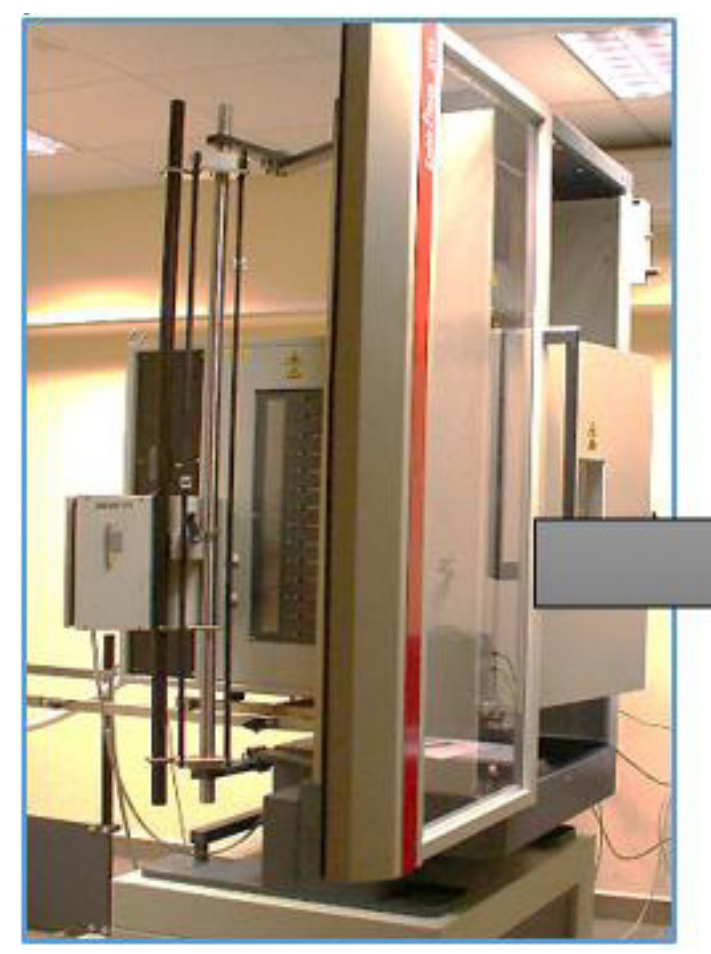

b)

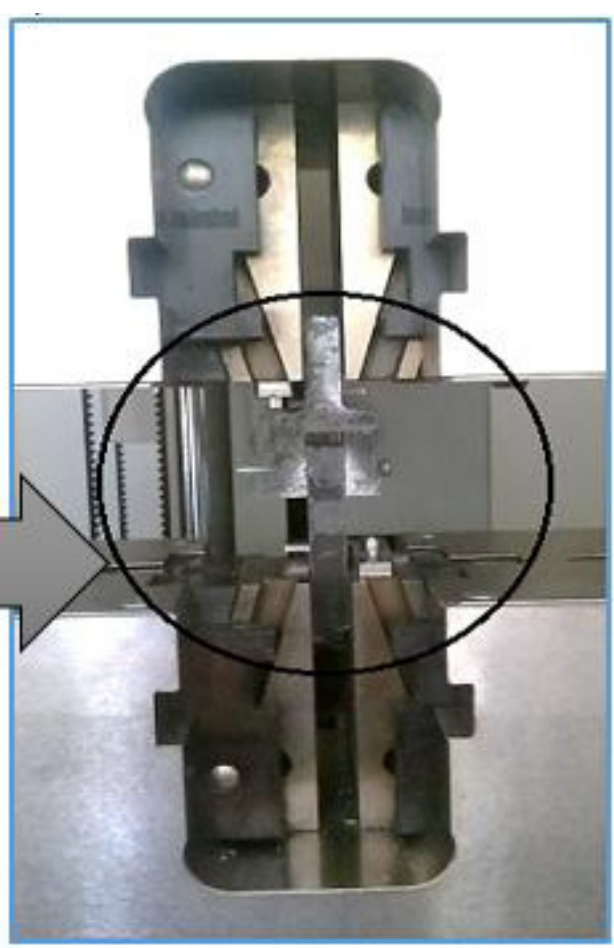

Fig. 5. Test stand: a) the ZWICK/ROELL Z150 testing machine, b) the special handle with attached sample 
a)

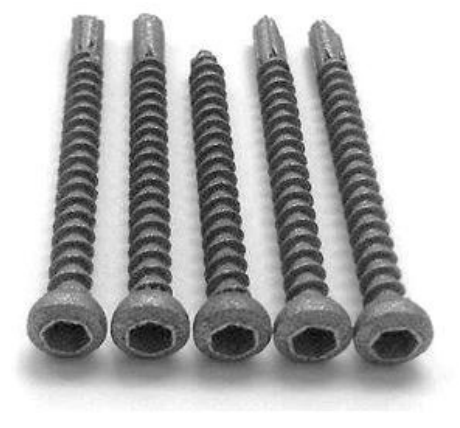

c)

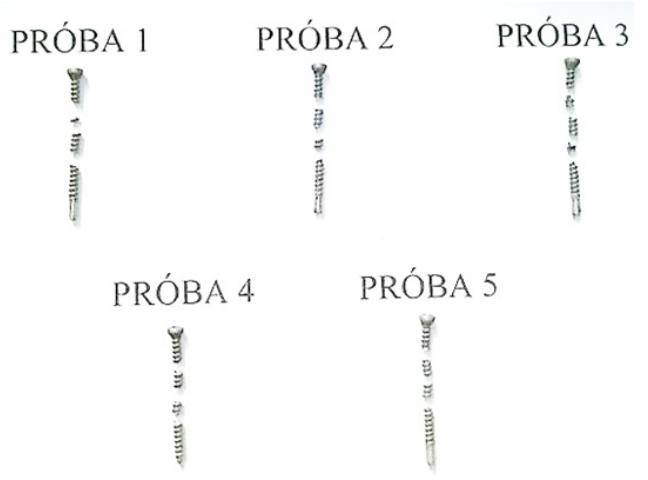

b)

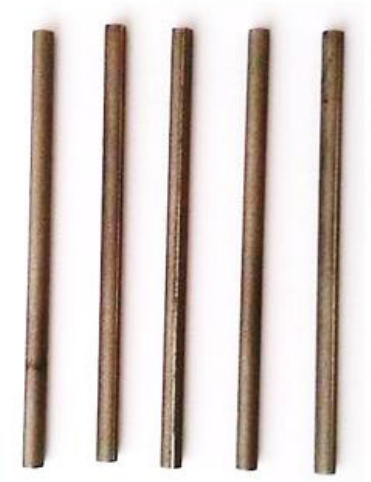

d)

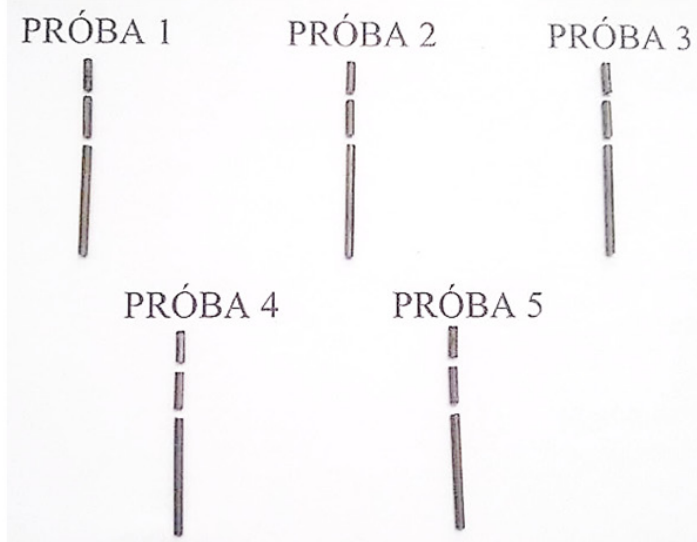

Fig. 7. The subject of research: a) orthopaedic screws made in the additive manufacturing technology, b) screws after the process of breaking, c) solid rods, d) rods after the process of breaking

oscillations of shear force at different values of elongation. It should be noted that they clearly illustrate the effect of the geometrical structure of screws on the course of the recorded force values. Fig. $8 \mathrm{~b}$ shows the results of a shearing test of samples made from monolithic Ti6A14V alloy. It reveals that the course of changes in the value of force is stable (no "oscillation of force"), and the observed elongations are slightly smaller. Tab. 5 provides a summary of the maximum force values recorded during the shearing test for each sample along with the maximum elongation for that force and their average values and standard deviations. The characteristics presented in Fig. 8a indicate much lower values of the recorded maximum force in a shearing test of the screws than in the case of monolithic rods, having the same cross section. The highest value of force in the shearing test of screws was $8383 \mathrm{~N}$, and the smallest was $4494 \mathrm{~N}$. As is apparent from Table 5 and Figure 8, the maximum difference between these values is signifi- cant and amounts to almost $100 \%$. This is also indicated by the $s$ dispersion. The value of standard deviation $(s)$ is very large and, according to the calculations, it is $1512 \mathrm{~N}$ (tab. 5). Figure $8 \mathrm{~b}$ shows the characteristics of force changes as a function of the elongation of rods cut from a solid titanium alloy. Based on Figure 8b, it can be concluded that the course of breaking in each test has a similar nature of changes. The lowest value of the maximum force was $9006 \mathrm{~N}$, while the highest was $10714 \mathrm{~N}$. This results from the fact that there was a higher reproducibility of results during shearing strength tests of rods than in the case of screws and lower value of the $s$ dispersion $(691 \mathrm{~N})$.

The samples of screws made in the additive manufacturing technology showed higher value of elongation (range: $(1,94 \div 3,6) \times 10^{-1} \mathrm{~mm}$ ) than monolithic samples of rods cut from a solid material (range: $\left.(2,07 \div 2,36) \times 10^{-1} \mathrm{~mm}\right)$.

The graphical interpretation of the measurement results was presented in Figure 9. The 
a)

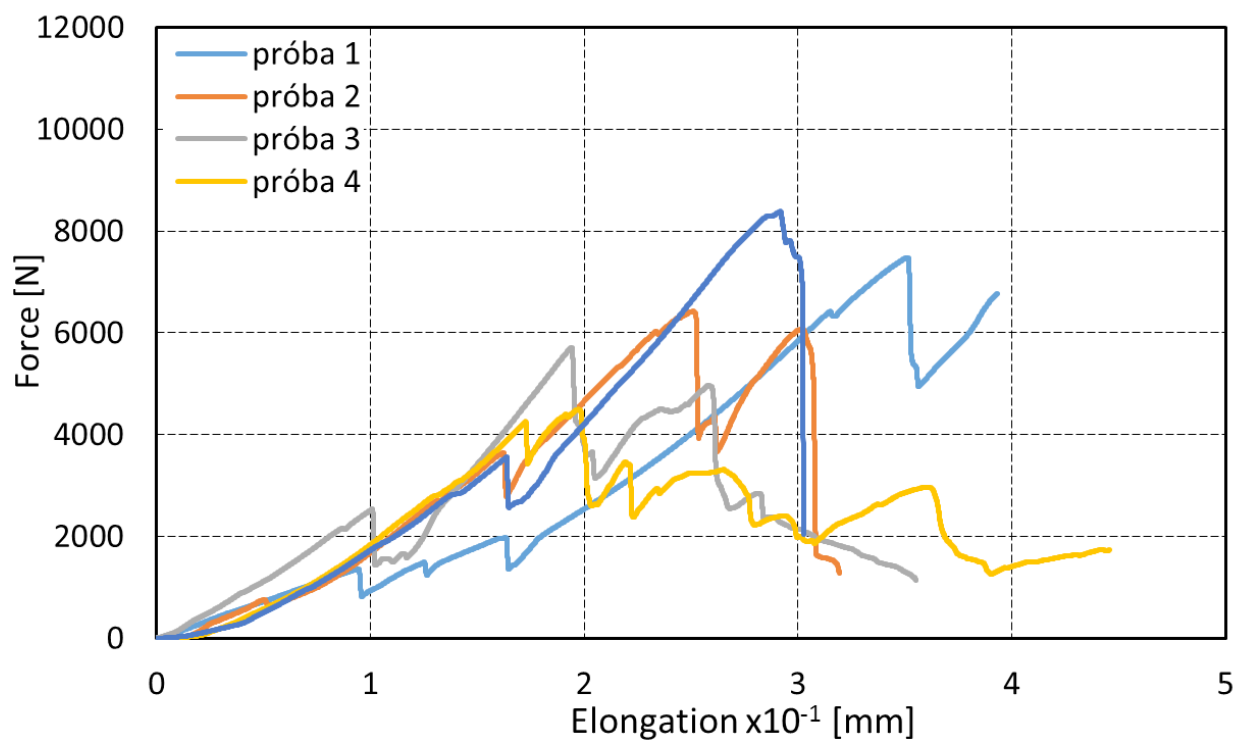

b)

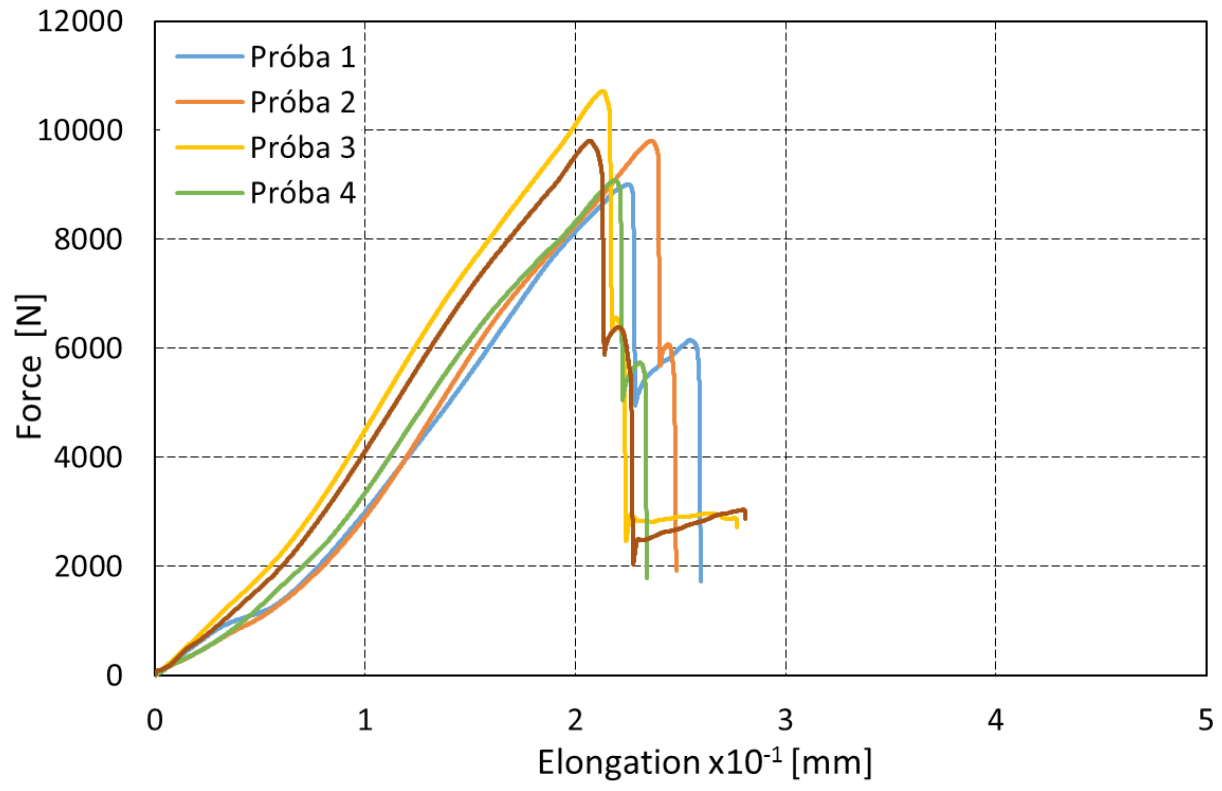

Fig. 8. The course of changes in force as a function of the elongation: a) for orthopaedic rods, b) for a solid rod made of titanium alloy

graphs presented in Fig. 9 show that samples that achieved the highest maximum force during the shearing test of monolithic rods, obtained the lowest elongation and a relatively small standard deviation. The trend of changes is reversed in the case of orthopaedic screws.

The conducted observations also show that the reason for this trend of changes is the cracking process of the studied screws, which resulted in higher elongation values than in the case of monolithic samples. However, it cannot be clearly stated that such a trend of changes is dependent only on the geometry of screws, and therefore, the research in this field should be continued.

\section{Strength calculations}

In order to calculate technological shearing strength, it was assumed that the direction of shearing force coincides with the vertical median line of the cross section of the studied screw (shearing centre coincides with the centre of gravity) and the tangential stress distribution is spread evenly throughout the entire cross section. The shear 
Table 5. The values of maximum force, elongation and statistical measures for each test

\begin{tabular}{|c|c|c|c|c|}
\hline \multirow[b]{2}{*}{ Test number } & \multicolumn{2}{|c|}{ for the printed orthopaedic screw } & \multicolumn{2}{|c|}{ for the solid rod } \\
\hline & Maximum force $F_{\text {max }}$ & $\begin{array}{l}\text { Elongation at maximum } \\
\text { strength } X\end{array}$ & Maximum force $F_{\max }$ & $\begin{array}{c}\text { Elongation at maximum } \\
\text { strength } X\end{array}$ \\
\hline & {$[\mathrm{N}]$} & $\mathrm{x} 10^{-1}[\mathrm{~mm}]$ & {$[\mathrm{N}]$} & $\mathrm{x} 10^{-1}[\mathrm{~mm}]$ \\
\hline 1 & 7477 & 3,60 & 9006 & 2,25 \\
\hline 2 & 6420 & 2,51 & 9805 & 2,36 \\
\hline 3 & 5715 & 1,94 & 10714 & 2,13 \\
\hline 4 & 4494 & 1,97 & 9081 & 2,19 \\
\hline 5 & 8383 & 2,92 & 9802 & 2,07 \\
\hline Average $\overline{\boldsymbol{F}}_{\text {max }_{x}} \overline{\boldsymbol{X}}$ & 6498 & 2,58 & 9682 & 2,20 \\
\hline Deviation $s_{F \max }, s_{x}$ & 1512 & 0,69 & 691 & 0,11 \\
\hline
\end{tabular}

a)

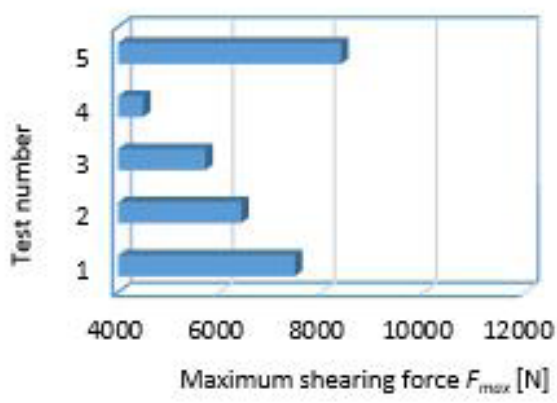

c)

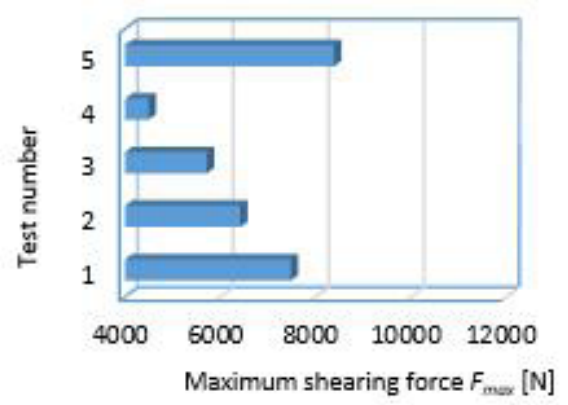

b)

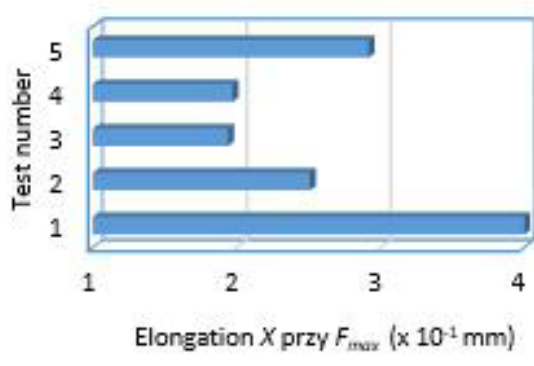

d)

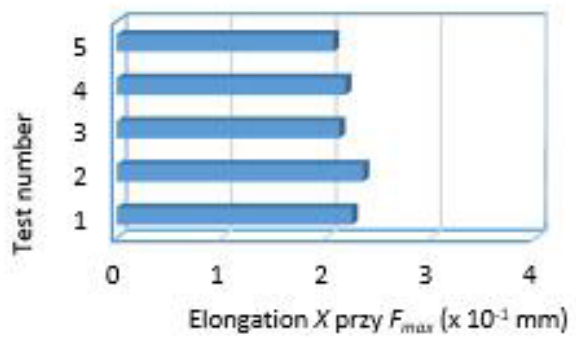

Fig. 9. The mechanical characteristics of the maximum shearing force values $F_{\max }$ and the elongation for individual strength tests $X: a)$ and $b$ ) for the printed orthopaedic screw from titanium alloy, c) and d) for the solid rod having a diameter of a core made of titanium alloy

stresses were averaged over the entire cross section $\left(\tau=\tau_{\text {str }}\right)$. The direction of shear stresses was determined as parallel to the direction of the applied force $F_{t}$, and the average value of shear stresses $\tau_{\text {sr }}$ was determined from the following relation (1):

$$
\tau_{\dot{s} r}=\frac{F_{t}}{\mathrm{~S}}
$$

where: $\tau$ - average shear stress, $\mathrm{F}_{\mathrm{t}}$ - external shearing force, $\mathrm{S}$ - cross sectional area.
The same load of the two sections was assumed taking into account the two shearing sections. The average value of the shear stress was calculated from the following equation (2):

$$
\tau_{\dot{s} r}=\frac{F_{t}}{2 S}
$$

Therefore, shearing strength $\mathrm{R}_{\mathrm{t}}$ was calculated taking into account the analysed case of attachment (corresponding to technological 
shearing), geometrical data of individual rods and screws and the values of maximum forces recorded in the individual test trials $\left(\mathrm{F}_{\max }\right)(3)$.

$$
R_{t}=\frac{F_{\max }}{2 S_{0}}=\frac{2 F_{\max }}{\pi d_{0}^{2}}
$$

where:

$\mathrm{F}_{\max }$ - is the highest force obtained during the shear test $[\mathrm{N}]$,

$\mathrm{S}_{\mathrm{o}}$ - cross-sectional area of the sample core,

$\mathrm{d}_{\mathrm{o}}$ - core diameter of the sample

Equation (3), which constitutes the basis for the calculation of $R_{t}$, is based on the assumption of even distribution of shear stresses in shearing sections and omission of stresses derived from bending. Therefore, the $\mathrm{R}_{\mathrm{t}}$ strength calculated in the above manner should be treated as a certain contractual and comparative measure. Equation (3) shows that the values of stresses are proportional to the maximum value of shearing force. The calculation results of shearing strength $R_{t}$ based on Equation (3) were shown in Table 6 and the comparative graphical presentation of the obtained calculation results were shown in Figure 10. The maximum shearing strength value $R_{t}$ of the screw was $1102.6 \mathrm{MPa}$ (for the maximum strength 8383 $\mathrm{N})$, and the minimum value was $591.1 \mathrm{MPa}$ at a rate of $4494 \mathrm{~N}$. The standard deviation $S_{R T}$ is very large and amounts to $177,89 \mathrm{MPa}$. The minimum value of shearing strength $R_{t}$ in the case of monolithic samples (rods) amounted to 1184.6 MPa (maximum force $9006 \mathrm{~N}$ ), and the obtained maximum value of shearing strength $R_{t}$ amounted to $1409.2 \mathrm{MPa}$ and corresponds to the maximum force of $10,713 \mathrm{~N}$. As in the case of maximum force in the shearing test of monolithic rods, shearing strength $R_{t}$ reaches average values $\left(\mathrm{s}_{\mathrm{Rt}}=81,36 \mathrm{MPa}\right)$.
The analysis of the results of empirical research shows that the $\mathrm{R}_{t}$ measure provides only an approximate assessment of the test material quality, and not its actual strength for pure shearing. Shearing strength $\mathrm{R}_{\mathrm{t}}$ determined in the above described manner can be regarded as a proxy indicator for the material quality in orthopaedic joints - a nail, as a counterpart to the knuckle or riveted joint, and the ratio of $R_{t}$ to the tensile strength $R_{m}$ can be used to assess the degree of compliance of the experience with the values recommended for the calculation of allowable shearing stress $k_{t}$ dependent on $\mathrm{k}_{\mathrm{r}}$.

a)

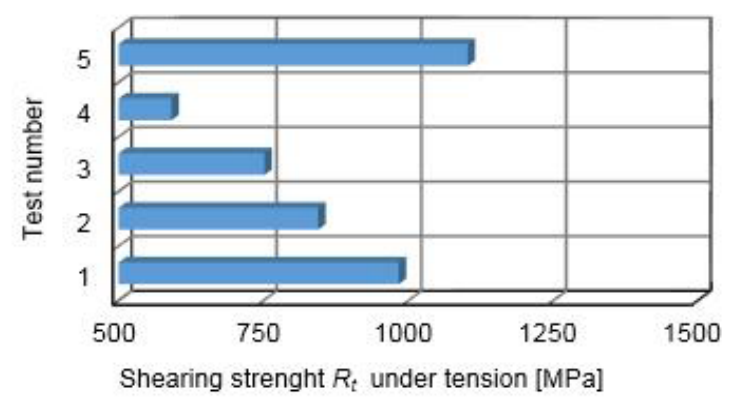

b)

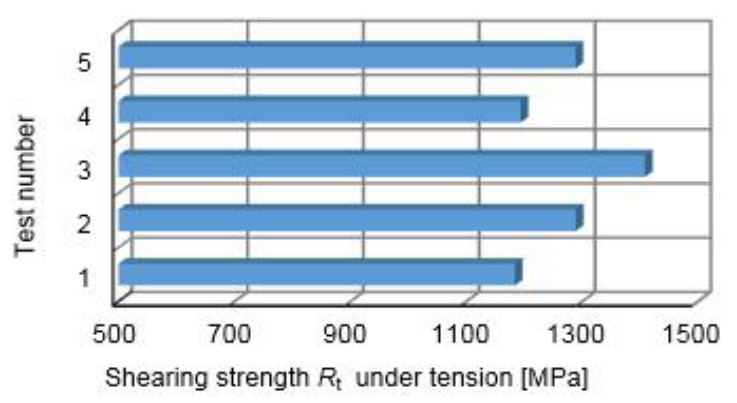

Fig. 10. The nature of changes in shearing strength under tension $R_{t}[\mathrm{MPa}$, for subsequent trials:

a) for the orthopaedic screw, b) for the solid core

Table 6. The values of shearing strength $R_{t}$ for each sample

\begin{tabular}{|c|c|c|}
\hline & \multicolumn{2}{|c|}{ Shearing strength $R_{\mathrm{t}}[\mathrm{MPa}]$} \\
\hline 1 & for the printed orthopaedic screw & for the solid core \\
\hline 2 & 983,5 & 1184,6 \\
\hline 3 & 844,5 & 1289,7 \\
\hline 4 & 751,7 & 1409,2 \\
\hline 5 & 591,1 & 1194,4 \\
\hline Average $\bar{R}_{\mathrm{t}}$ & 1102,6 & 1289,6 \\
\hline Deviation $\mathrm{s}_{\mathrm{Rt}}$ & 854,6 & 1273,4 \\
\hline
\end{tabular}




\section{CONCLUSIONS}

The paper presents a comparative evaluation of technological shearing strength of orthopaedic screws and monolithic rods made of the same material. Based on the conducted research, it can be stated that:

1. Shearing strength $R_{t}$ of orthopaedic screws is approx. 33\% lower than that of monolithic rods with the same diameter as the screw core.

2. Screws, as compared to monolithic rods from titanium alloy, obtained smaller values of the maximum force under breaking and much more varied results; standard deviation values were respectively: s1: $1512 \mathrm{~N}$ for screws and s2: $691 \mathrm{~N}$ for rods.

3. The precision of printed elements, in particular the lack of continuity of the material, can have a significant impact on the strength.

4. Technological and material conditions may influence the results of strength tests, e.g. incorrect printing speed, humidity of titanium alloy powder in the manufacturing process, improperly structured supports necessary during printing and other.

5. 3D printing makes it possible to print orthopaedic screws, designed for mounting medical nails or plates.

\section{REFERENCES}

1. Ambroziak M.: Stapianie proszków wiązką lasera - SLM. Wadim Plast. Nowości techniczne TS RAPORT nr 35, 2004.

2. Bose S., Vahabzadeh S., Bandyopadhyay A.: Bone tissue engineering using 3D printing, Materials Today, Vol. 16, 2013, 496-504.

3. Brunello G., Sivolella S., Meneghello R., Ferroni
L., Gardin C., Piattelli A., Zavan B., Bressan E.: Powder-based 3D printing for bone tissue engineering, Biotechnology Advances, Vol. 34, 2016, 740-753.

4. Chassaing G., Pougis A., Philippon S., Lipinski P., Faure L., Meriaux J., Demmou K., Lefebvre A.: Experimental and numerical study of frictional heating during rapid interactions of a Ti6Al4V tribopair, Wear, Vol. 342-343, 2015, 322-333.

5. http://slm-solutions.com/products/machines/slmr280hl ( $\mathrm{z}$ dn. 23.05.2016).

6. Maciejewski R., Zubrzycki J.: Inżynieria biomedyczna. Wybrane obszary zastosowań. Politechnika Lubelska, Wyd. Politechnika Lubelska, Lublin 2012.

7. Melechow R., Tubielewicz K., Błaszczuk W.: Tytan i jego stopy. Politechnika Częstochowska, Częstochowa 2004.

8. Nersisyan H., Yoo B., Kim Y., Son H., Lee K., Lee J.: Gas-phase supported rapid manufacturing of Ti6Al-4V alloy spherical particles for 3D printing, Chemical Engineering Journal, Vol. 304, 15 November 2016, 232-240.

9. Norma PN-EN ISO 5832-3:1996: Implants for surgery. Metallic materials. Part 3: Wrought titanium 6-aluminium 4-vanadium alloy.

10. Oczoś K.: Nowe materiały w procesach kształtowania przyrostowego wyrobów. Mechanik, 2007, No. 3, 127-130.

11. Orlicki R., Kłaptocz B.: Tytan i jego stopy właściwości, zastosowanie w stomatologii oraz sposoby przetwarzania, Inżynieria Stomatologiczna Biomateriały Tom I nr 1/2005, 3-8.

12. Przybylski P.: Wykorzystanie technologii druku 3D w projektowaniu chwytaków robotów przemysłowych, Mechanik, No. 7, 2016, 804-805.

13. Siemiński P., Budzik G.: Techniki przyrostowe. Druk 3D. Drukarki 3D. Oficyna wydawnicza Politechniki Warszawskiej, Warszawa 2015.

14. Wierzchoń T., Sobiecki J.R.: Tytan i jego stopy. VIII Ogólnopolska Konferencja, Warszawa - Serock, 24-26.10.2005. 